\title{
Classroom Discourse: Pattern of Interaction of Talk Between Students in Primary Science Classrooms in Indonesia
}

\author{
Munasprianto Ramli, Media Putri Yohana \\ Syarif Hidayatullah State Islamic University Jakarta, Jl. Ir. H. Djuanda 95, Ciputat, Indonesia \\ Corresponding e-mail: munasprianto ramli@uinjkt.ac.id
}

\begin{abstract}
Classroom talk has been the subject of research over the last forty or so years. In the field of science education, dialogue has become a central issue in developed countries within last twenty years. Although the research focused in this topic grows rapidly in western country, this was not a case in Indonesia. There is very limited study published about classroom talk in Indonesia. This study aimed to explore the pattern of interaction during talk in primary science classroom which implemented curriculum 2013 (K 13). An exploratory case study was employed in this qualitative research. Data were collected for a period of 6 months by video recording lesson of the whole classroom discussion in one primary school in Greater Jakarta Indonesia. Data were analyses using thematic analysis. The finding indicates that the dialogue between students follow both traditional triadic pattern (Initiation response feedback/IRF) -and non-triadic pattern (open and closed interaction chains).
\end{abstract}

Keywords: dialogic education, classroom talk, primary science, curriculum 2013

\section{INTRODUCTION}

The classroom is an environment in which talk is facilitated, whether between teachers and students, or among students themselves. Such discussion plays a major role in the teaching-learning process. Educational researchers have paid serious attention to the topic of classroom talk and studies have been conducted over the last 40 years. In the field of science education, classroom talk has become a central issue in developed countries over the last 20 years. However, this is not the case for Indonesia, where there is very little published research on classroom talk in science education. To contribute to the development of science education in Indonesia I conducted this research. This study aims to explore the pattern of interaction of talk between students in primary science classrooms that implement the new integrated curriculum in Indonesia. In order to achieve this purpose, I am addressing the following research questions (RQ) " what are the patterns of interaction of talk between students in the primary science lesson?
To analyse and to understand classroom talk a number of researchers examine the structure and pattern of interaction between teacher and students during talk (for example, Lemke 1990, Wegerif 1996, Mortimer and Scott 2003). Sinclair and Couldthard (1975) identified a three-part sequence operates in classroom discourse called IRF. The classroom talk starts with an initiation (I) from the teacher which will stimulate students' response $(\mathrm{R})$. Then, this interaction will be followed by the feedback comment from the teacher (F). Similarly, Mehan (1979) introduced a cycle of IRE as a typical exchange in a classroom interaction. An example of both three-part sequences which called triadic pattern by Lemke (1990) can be seen in the table bellow: 


\begin{tabular}{|c|c|c|c|}
\hline \begin{tabular}{l}
\multicolumn{2}{c}{ Teache } \\
r: Can you \\
tell me \\
why do \\
you eat all \\
that food? \\
\multicolumn{2}{c}{ Yes }
\end{tabular} & ion ${ }^{\text {Initiat }}$ & $\begin{array}{l}\text { Teacher } \\
: \quad \text { And } \\
\text { whose is } \\
\text { this? }\end{array}$ & $\begin{array}{l}\text { Initiati } \\
\text { on }\end{array}$ \\
\hline $\begin{array}{l}\text { Paul : } \\
\text { To keep } \\
\text { you strong }\end{array}$ & nse ${ }^{\text {Respo }}$ & $\begin{array}{l}\text { Many: } \\
\text { Veronica. }\end{array}$ & se ${ }^{\text {Respon }}$ \\
\hline \begin{tabular}{l}
\multicolumn{2}{c}{ Teache } \\
$\mathrm{r}:$ To keep \\
you strong. \\
Yes. To \\
Keep you \\
strong. \\
Why do \\
you want \\
to be \\
strong?
\end{tabular} & ${ }_{\text {ack }}$ Feedb & $\begin{array}{l}\text { T: Oh, a } \\
\text { lot of } \\
\text { people } \\
\text { knew } \\
\text { that one. }\end{array}$ & $\begin{array}{l}\text { Evalua } \\
\text { tion }\end{array}$ \\
\hline \multicolumn{2}{|c|}{$\begin{array}{l}\text { (Sinclair and } \\
\text { Coulthard } 1975, \text { p.21) }\end{array}$} & \multicolumn{2}{|c|}{ (Mehan 1979, p. 52) } \\
\hline
\end{tabular}

The educational researchers from diverse countries have been focusing their investigation on these triadic patterns over the years. For example, Cazden (1983, 1988) and Waring (2009) examined the pattern of classroom talk in the United States of America. Chin (2006) and Liu (2008) analysed the triadic model in teacher and students during classroom discussion in Singaporean schools. Candela (1998) studied a class in Mexico to look at the triadic model relating to student power in accordance with the triadic pattern during classroom interaction. Li (2011) examined students' obstacles and opportunities during interaction in language classroom in China by looking at IRE and IRF patterns. Hardman et al. (2008) investigated the triadic pattern in primary classrooms in Nigeria, and Hardman (2001) studied classroom interaction in a Kenyan primary school.

However, due to the fact that students are encouraged to provide extensive responses (Viiri and Sari 2006), researchers developed an alternative to the triadic pattern (Wegerif 2006 and Mortimer and Scott 2003). Wegerif (1996) introduced the IDRF structure, which proposes discussion between teacher initiation and students' response. He carried out a study which analyse pattern of exploratory talk during computer assisted lesson in which groups of school students working with a variety of educational software. During the interaction, it appears that student discusses with each other, and this action occurs between initiation and response move. Mortimer and Scott (2003) proposed the open and closed interaction chains (I-R-F-R-F-R and I-R-F-R-F-R-F). They analysed talk in secondary science classroom and found that teacher offers elaborative feedback which is followed by students' further response. Some classroom talk end with feedback from the teacher (closed interaction) whilst others remain open without feedback.

\section{METHODS}

Over the last three decades, various approaches have emerged within the qualitative research paradigm, such as ethnography, grounded theory, case study, phenomenology, and historical research (Creswell 2009). Given the fact that the present study aims to explore in-depth the talk in primary science classrooms in Indonesia implementing the new curriculum (Curriculum 2013), a case study is a suitable approach for this study.

Our research was carried out in year four at two primary schools in Greater Jakarta, Indonesia. Video recording of ten science lessons were made in each classroom. Two teachers, Mr Dono and Mrs Diana, agreed to participate voluntarily in this study. The lesson topics were selected through discussion with each teacher, which based on the guidance of the Curriculum 2013. As researchers, we made no intervention on lesson plan, classroom instruction and assessments. However, we shared the focus of the study with the teachers to make it clear the objective of our research.

This paper draws only the data gathered from classroom observations. To be objective in this study, we maintained a clear relationship between observer and participant. We decided to have a position of the observer as a participant stance, where we had minimal interaction with teacher and students in the classroom setting being studied. By applying this position, the participants knew my activities, and we had access to participants' activities and information. Data gathered were analyse using thematic analysis to look at the pattern interaction adapted during each excerpt.

\section{RESULTS AND DISCUSSION}

Classroom observations indicated that both triadic (IRF) and nontriadic patterns (I-R-F-R-F) chains were adapted during primary science classroom. Three excerpts from talk between students and 
pattern of interactions adapted discussed in the following sections.

\subsection{Excerpt 1: Talk between students on birds of paradise Titles}

The teacher asked his students to read the passages in birds of paradise and asked them to work in groups to find the differences and similarities between species of cenderawasih birds (birds of paradise/Paradisaeidae). The dialogue below took place when students discussed the differences and similarities between the red cenderawasih and the blue cenderawasih.

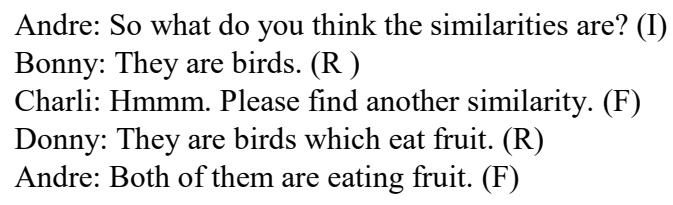

As can be seen from the extract, Andre initiates the discussion by posing the question, "So what do you think the similarities are?" The ironic response of Bonny, "They are birds", followed by a feedback from Charli, "Please find another similarity." In response to this feedback, the students proposed that the species is identified a fruit-eating bird. Finally, Andre closed this chain with his feedback, "Both of them are eating fruit." It is clearly seen that the pattern of the dialogue is different from the classic IRF. The dialogue shows a non-triadic pattern of IRFRF instead of IRF.

The dialogue continues by the initiation of Charli who asks "can we say that these birds are herbivore birds?"

Charli: Can we say that these birds are herbivore birds? (I)

Bonny: Yes. Herbivore birds. Why not Barbievore birds? (R)

Andre: (Laughs) Barbievore birds, birds which eat Barbie, you are funny. (F)

Donny: What else? (I)

Bonny: Both can fly. (R)

Andre: For sure, all the birds can fly. (F)

Bonny: Not all birds can fly (R)

As can be seen from the extract, it is important to note that the students proposed the notion of herbivore despite it not being in the textbook, thereby demonstrating that students formulate ideas by drawing on alternative sources. This may be from previous lessons or from their daily experiences such as from the books and magazines they read or from TV programmes.

It is interesting to note that students displayed their ability to make an analogy of herbivore and barbievore. Andre offered the definition of barbievore as the bird that eats Barbie, showing how students are able to develop scientific literacy through talking. In this case, students demonstrated their ability in explaining the concept of herbivore by concluding that the birds that eat fruit are herbivores and showing their understanding of the word vore, which means eat or swallow. The above extract highlights the classic IRF pattern, despite the final utterance being made in Bonny's challenge of Andre's feedback.

\subsection{Excerpt 2: Talk between Students on Biotic and Abiotic Resources}

The dialogue below took place when students learned the topic of biotic and abiotic natural resources. After reading the passages pertaining to natural resources in certain areas, Mr. Dono encouraged his students to discuss in groups the sample of biotic and abiotic natural resources they may find around the school.

Amin: What is abiotic? (I)

Fatih: Abiotic are those which are non-living. (R)

Budi: What about seaweed? (I)

Fatih: Seaweed is biotic (R)

Budi: Why not abiotic? They are not moving? (R)

Fatih: But they are plants. Plants are biotic. (F)

Similar to the first episode, this section is not adapted to the classic IRF pattern; instead it shows another chain, the IRIRRF pattern. Talk was initiated by a genuine question raised by Amin, who asked about the concept of abiotic. This implies that he was not sure about his understanding of the concept of abiotic, so he needed a better understanding before discussing the sample of abiotic natural resources. In response to this initiation, Fatih offered the definition of abiotic. This response encouraged Budi to ask another question, "What about seaweed?" Again, Fatih provided the answer that seaweed is biotic. Based on his experiences, Budi challenged the idea of seaweed as a biotic resource, since they do not move like living organisms. Dealing with this challenge, Fatih clarify that seaweed is a plant and all plants are biotic.

The dialogue continued when Amin reiterated his enquiry on the task given.

Amin: So what are examples of abiotic? (I)

Budi: Water, gold, soil. (R)

Fatih: Water is biotic. (R) 
Budi: No it's abiotic. ( R)

Fatih: But it moves and it is renewable. (R)

Budi: But water is not living thing so it's abiotic. (R)

Fatih: Ok. What date is it today? $(\mathrm{F} / \mathrm{I})$

Amin: It's the $20^{\text {th }}$.

Fatih: Oh, it's my little brother's birthday.

Amin: My mom's is on the $23^{\text {rd }}$.

Budi: None of my family has their birthday in this month.

In line with the previous section, the pattern of this section is a non-triadic pattern, called IRRRRRF. Amin initiated the further discussion by stating the question "so what are examples of abiotic?" In response to this initiation, Fatih and Budi shared their ideas about the topics to express their understanding of it and also to contribute to the dialogue. Then, the dialogue shifted after Fatih showed his feedback by saying, "OK", and initiated a non-curriculum talk on birthday dates.

\subsection{Excerpt 3: Talk between Students on Electrical Appliances}

This dialogue was instigated when Mrs. Diana asked students to discuss technology in pairs, based on the task set out in the textbook. The textbook presented pictures of electronic appliances used in daily life. Students were asked to consider what would happen if the appliances were used continuously and the reasons for it. In addition to that question, students were also asked if they could make such an appliance for helping human activities.

Dessy: What will happen if electronic appliances are used continuously?

Nina: They will be broken.

Dessy: What do you mean?

Nina: They will be broken if we use them continuously

Dessy: What is the reason?

Nina: Hmm no idea.

Dessy: It may not work anymore I think.

Nina: Next, if you were asked to make an electrical appliance to help humans, what would you make?

Dessy: Magic jar to cook rice

Nina: Why?

Dessy: So one will not be tired when cooking rice; the rice will stay warm and ready to eat at any time. Or I may make an automatic iron.

Nina: What for?

Dessy: So it will help ironing and the clothes are always tidy.

Nina: What is its drawback?

Dessy: A hot iron can leave burn marks on clothing.

This dialogue began when Dessy read the question from the textbook. It can be said that Dessy initiated this dialogue by conveying the question "What will happen if electronic appliances are used continuously?" Nina responded to this question and stated that the equipment may be damaged. Dessy showed her feedback by asking for confirmation of what Nina meant by ''damaged." Nina then repeated and confirmed that the equipment would be damaged if used continuously. Wanting to explore further, Dessy asked Nina's opinion about the reasons for it being damaged. However, Nina did not have any ideas, so Dessy concluded that the equipment would be finished. In this case, Dessy might have used the word 'finish' to describe that the appliance could no longer be used.

After this, Nina took over the role as the pupil who asked by delivering the question "What would you make if you were asked to make an electronic appliance to help humans". In response to this question, Dessy conveyed the idea of making a rice cooker. Exploring Dessy's idea, Nina asked her why she wanted to make a rice cooker. Dessy did not only give a reason why she wanted to make rice cooker, but brought a new idea: making an automatic iron. The dialogue then became extended by Dessy reasoning and the drawback of an automatic iron.

From the above description, a traditional IRF pattern emerged. However, interestingly, the episode did not follow the standard IRF model. In the traditional IRF, the teacher acts as initiator and feedback provider, while students are responders. It did not appear to happen in this dialogue. Both Dessy and Nina shared the same role. At the beginning of the episode, Dessy took the position of the initiator and gave feedback, while at the end Nina took this role. This evidence shows that the two students had the same position: none of them had dominance and had a higher authority.

\section{CONCLUSIONS}

The study suggests that talk between students during science lesson in primary schools in Indonesia adapted both triadic (IRF Pattern) and nontriadic pattern (IRFRF chain). The IRF pattern adapted when one or more students take a role of a teacher and the nontriadic pattern adapted when students show similar authoritative position. The findings of this study are subject to the limitation in which the number of samples available for this study certainly makes the generalisability of these results subject to cautious interpretation. For that we recommend the research could be replicated at the primary school across Indonesia, and it would be interesting to compare the experiences of teachers and students from different regions across the country. In 
addition, to enrich the literature in this field, research on similar topics could also be carried out in secondary schools to see how classroom talk is promoted in biology, chemistry and physics classrooms in Indonesia.

\section{ACKNOWLEDGEMENTS}

The authors wish to thank Faculty of Education Sciences UIN Syarif Hidayatullah Jakarta.

\section{REFERENCES}

Candela, A. (1998). Students' power in classroom discourse. Linguistics and Education, 10(2), 139-163

Cazden, C. B. (1988). Classroom discourse: The language of teaching and learning. Portsmouth, $\mathrm{NH}$ : Heinemann.

Cazden, C. B., Beck, S. W. (2003). Classroom discourse. In A. C. Graesser, M. A. Gernsbacher, \& S. R. Goldman (Eds.), Handbook of discourse processes. New York, NY: Routledge.

Chin, C. (2006). Classroom Interaction in Science: Teacher questioning and feedback to students' responses. International Journal of Science Education, 28(11), 1315-1346.

Creswell, J. W. (2009). Research design: Qualitative, quantitative, and mixed method approaches. Thousand Oaks, CA: Sage Publications.

Hardman, F., Abd-Kadir, J., Smith, F. (2008). Pedagogical renewal: Improving the quality of classroom interaction in Nigerian primary schools. International Journal of Educational Development, 28(1), 55-69.

Hardman, J. A. (2001). Classroom Interaction in Kenyan Primary Schools. Compare, 31(2), 245-261.

Lemke, J. L. (1990). Talking science: Language, learning, and values. Norwood, NJ: Ablex Pub. Corp.

Mehan, H. (1979). Learning lessons: Social organization in the classroom. Cambridge, MA: Harvard University Press.

Mortimer, E., \& Scott, P. (2003). Meaning Making in Secondary Science Classrooms. Open UP.

Sinclair, J., \& Coulthard, M. (1975). Towards an analysis of discourse: The English used by teachers and pupils. London: Oxford University Press.

Viiri, J., \& Saari, H. (2006). Teacher Talk Patterns in Science Lessons: Use in Teacher Education. Journal of Science Teacher Education, 17(4), 347-365.

Waring, H. Z. (2009). Moving out of IRF (InitiationResponse-Feedback): A Single Case Analysis. Language Learning, 59(4), 796-824.

Wegerif, R. (1996). Using computers to help coach exploratory talk across the curriculum. Computers \& Education, 26(1-3), 51-60.
Wegerif, R. (2005). Reason and Creativity in Classroom Dialogues. Language and Education, 19(3), 223-237. 